\title{
Cooperative Model of Industrial Work Practice for Vocational Teacher Education
}

\author{
Ahmad Sonhadji ${ }^{1}$, K. Hasan \\ Department of Mechanical Engineering, Engineering Faculty, State University of Malang, \\ Malang, INDONESIA \\ 1asonhadjikh@yahoo.com
}

\begin{abstract}
The industrial work practice is assumed to strengthen the vocational discipline for students of vocational teacher education program. One of models of industrial work practice is cooperative education. The objectives of the study are to know: (1) the advantages of cooperative education, (2) the differences of cooperative education, dual system, and "traditional industrial work practice" (prakerin), (3) the training program of cooperative education for vocational teacher education compared to that of prakerin, and (4) the policies which should be developed to implement this program in Indonesia. The method used is library research with meta-analysis and qualitative approach. The results of the study are: (1) the cooperative education has many advantages, (2) the cooperative education is more complex than "prakerin", but more simple than dual system, (3) the training program of cooperative education for vocational teacher education is more complete than that of prakerin, and (4) some policies should be made for applying the cooperative education. The implication of the study is that cooperative model can be implemented to reform the current prakerin, with several modifications.
\end{abstract}

Index Terms - cooperative education, industrial work practice, vocational teacher education

\section{Introduction}

Indonesia needs to prepare human resources capability for industries and business, especially in facing the global competition. It is assumed that quality of human resources leads to efficiency of process, quality of product, and customer satisfaction. In this issue, the role of vocational schools is very important. Vocational education is education for work. Thus, vocational schools should continuously improve a quality of graduates with knowledge and skills needed in the world of works. Teacher is the key of educational process and output at vocational schools. The teacher education has a strategic role in producing professional teachers. Hill-Jackson \& Lewis [1] have asserted that transforming teacher education is urgent because of current weaknesses of the school performance. They have elaborated that transformation of teacher education endorses revolutionary and authentic alternation in vision, implementation, methods of accountability, and reinvention of teacher education programs.

Danelson [2] have explained that one of components of teacher professional practice is demonstrating knowledge of content and pedagogy. He has insisted, "a person cannot teach what he or she does not know". Moreover, teachers have to use pedagogical techniques to assist delivery information and teach specific skills. The content and pedagogy competences of teachers should become critical attention in teacher education.

For Indonesia, the competences of teachers are stated on the Regulation of Ministry of National Education Number 16 of 2007 on Teacher Competences. According to the regulation, each teacher is required to have four competences: pedagogical competence, personality competence, social competence, and professional competence. It is assumed that the industrial work practice can enhance professional competence of vocational teachers, especially associated to their skills and attitudes on the productive areas. In fact, teacher education institutions (LPTKs) have some problems related to the industrial work practice for their students. They do not have appropriate system of industrial work practice. The linkage of LPTKs and industries are mostly incidental and sporadic. There is no systematic network between the vocational teacher education and related industries. The condition causes students of vocational teacher education are difficult to find places of practice, as well as to optimally do their programs. It is expected that the cooperative model can solve the problems.

Cooperative education is a model of collaboration between educational institution and business-industry. In the United States the program has strong legal foundations, supported by community and government, well organized, and has detailed and operational components of activities. The legal base of cooperative education in the USA is Vocational Act (Amendment), [3]. The act has stated as following:

"Cooperative education is a program of vocational education for persons who, through written cooperative arrangements between the school and employers, receive instruction by alternation of study in school with a job in any occupational field. These two experiences must be planned and supervised by the school and employers so that each contributes to students' education and employability. Work periods and school may schedule on alternate half days, full days, weeks, or other periods of time".

Basically, cooperative education is a work practice program supported by written joint agreement between school and industry. Students receive instruction at school and work at industry. The program is well designed and supervised both by the school and the industry. Meanwhile, Canadian Association for Cooperative Education [4] defines cooperative education as a program which alternates periods of academic study with work experience in relevant fields of business, industry, government, social services, and the professions. The main characteristics of cooperative education are: (1) having written agreement between the school and the industry, (2) providing work experiences appropriate to the career goal, (3) rotation of learning at school and working at industry, and (4) students who work at industry receive wages referred to the related law [5].

The study was done based on these questions. What are the advantages of cooperative education? What are the basic differences between cooperative education, dual system, and 
prakerin? What is the feature of the cooperative model for vocational teacher education compared to that of prakerin? What policies can be developed and decided to implement this model in Indonesia?

\section{Methods}

The study was conducted by using the method of library research. Data was collected through the relevant references, manuals, and findings of previous studies related to cooperative education, dual system, and prakerin practices. On this study, meta-analysis was employed with qualitative approach. The results of the analysis were identifications, comparisons and contrasts, domains, and policy formulations.

\section{Results and Discussion.}

The advantages of cooperative education are viewed according to the three domains: students, school/university, and industry. The study has shown the graduates who have participated on cooperative education get permanent jobs more rapidly, feel more satisfied to their jobs, receive higher wages, receive better appraisal to their performances, and have positive attitude toward their schools and works. Meanwhile, the academic institution gets benefits of receiving practical input from professional community, and can strengthen the collaboration between school/university and industry. Finally, with this program industry obtain new theories and ideas from school/university, and the cooperative programs can minimize problems of searching and training for manpower, in which training programs at industry can be more efficient with the "ready work" candidates who participated on cooperative education. The benefits are shown on Table 1.

Table 1. The Advantages of Cooperative Education

\begin{tabular}{|c|c|c|}
\hline No. & Domains & Benefits \\
\hline 1. & Students & $\begin{array}{l}\text { The graduates who have } \\
\text { participated on cooperative } \\
\text { education get permanent } \\
\text { jobs more rapidly, feel more } \\
\text { satisfied to their jobs, } \\
\text { receive higher wages, } \\
\text { receive better appraisal to } \\
\text { their performances, and have } \\
\text { positive attitude toward their } \\
\text { schools and works. }\end{array}$ \\
\hline
\end{tabular}

2. School/University Receive practical input from professional community, and can strengthen the collaboration between school/university and industry.

3. Industry
From this study the author state that the cooperative education is more complex than "prakerin", but more simple than dual system. The differences between the three models are featured in three aspects: principle, management system, and elements of organizational structure. The comparison between cooperative education, dual system, prakerin is indicated on Table 2 .

Table 2. Comparison between Cooperative Education, Dual System, and Prakerin.

\begin{tabular}{|c|c|c|c|c|}
\hline No & Aspects & $\begin{array}{l}\text { Cooperative } \\
\text { Education }\end{array}$ & $\begin{array}{l}\text { Dual } \\
\text { System }\end{array}$ & Prakerin \\
\hline 1. & Principle & $\begin{array}{l}\text { The } \\
\text { educational } \\
\text { program is } \\
\text { basically } \\
\text { placed at } \\
\text { school; } \\
\text { however a } \\
\text { part of } \\
\text { activities is } \\
\text { done at } \\
\text { industry }\end{array}$ & $\begin{array}{l}\text { The } \\
\text { education } \\
\text { al } \\
\text { program is } \\
\text { conducted } \\
\text { at two } \\
\text { places, } \\
\text { those are } \\
\text { the school } \\
\text { and the } \\
\text { industry }\end{array}$ & $\begin{array}{l}\text { The } \\
\text { educational } \\
\text { program is } \\
\text { basically } \\
\text { placed at } \\
\text { school; } \\
\text { however a } \\
\text { part of } \\
\text { activities is } \\
\text { done at } \\
\text { industry }\end{array}$ \\
\hline 2. & $\begin{array}{l}\text { Managem } \\
\text { ent } \\
\text { System }\end{array}$ & $\begin{array}{l}\text { It is } \\
\text { properly } \\
\text { designed }\end{array}$ & $\begin{array}{l}\text { The dual } \\
\text { system } \\
\text { has very } \\
\text { strong } \\
\text { planning }\end{array}$ & $\begin{array}{l}\text { It is weakly } \\
\text { planned }\end{array}$ \\
\hline 3. & $\begin{array}{l}\text { Elements } \\
\text { of } \\
\text { Organizati } \\
\text { onal } \\
\text { Structure }\end{array}$ & $\begin{array}{l}\text { Consists of } \\
\text { advisory } \\
\text { committee, } \\
\text { administrato } \\
\text { r, } \\
\text { coordinator, } \\
\text { supervisor, } \\
\text { student, and } \\
\text { parent }\end{array}$ & $\begin{array}{l}\text { Consists } \\
\text { of school } \\
\text { committee } \\
\text {, principal, } \\
\text { work } \\
\text { team, } \\
\text { teacher, } \\
\text { and pair } \\
\text { institution } \\
\text { (industry) }\end{array}$ & $\begin{array}{l}\text { Prakerin has } \\
\text { three } \\
\text { elements: } \\
\text { principal/depa } \\
\text { rtment chair, } \\
\text { industry, and } \\
\text { student. }\end{array}$ \\
\hline
\end{tabular}

Table 2 shown that cooperative education program and prakerin are basically placed at school; however, a part of activities respectively is done at industry. Dual system is a model in which educational program is conducted in two places, those are school and industry. Moreover, the management system of cooperative education is properly designed, dual system has very strong planning, while prakerin is weakly planned. Related to the organizational structure, cooperative education consists of advisory committee, administrator, coordinator, supervisor, student, and parent. Dual system organization comprise of school committee, principal, work team, teacher, and pair institution (industry). On the other hand, prakerin only has three elements: principal/department chair, industry, and student.

The cooperative education has better training program than prakerin, especially for vocational teacher education. At least, three components those has shown the comparison, namely the training agreement, the training plan, and the training station. Table 3 indicates the comparison. 
Table 3. Comparison between the Training Program of Industrial Work Practice of Cooperative Education and Prakerin for Vocational Teacher Education

\begin{tabular}{|c|c|c|c|}
\hline No. & Components & Cooperative Education & Prakerin \\
\hline 1. & $\begin{array}{l}\text { Training } \\
\text { Agreement }\end{array}$ & $\begin{array}{l}\text { Written training } \\
\text { agreement are signed } \\
\text { by student, academic } \\
\text { advisor, department } \\
\text { chair, coordinator, and } \\
\text { supervisor. }\end{array}$ & $\begin{array}{l}\text { No written training } \\
\text { agreement. }\end{array}$ \\
\hline 2. & Training Plan & $\begin{array}{l}\text { Training plan consists } \\
\text { of career goal, learning } \\
\text { experiences, students } \\
\text { tasks, nature and scope } \\
\text { of the program, work } \\
\text { location, and time } \\
\text { frame. }\end{array}$ & $\begin{array}{l}\text { Training plan is just } \\
\text { generally covered } \\
\text { on the guidance of } \\
\text { work practice } \\
\text { written by the } \\
\text { department chair. }\end{array}$ \\
\hline 3. & $\begin{array}{l}\text { Training } \\
\text { Station }\end{array}$ & $\begin{array}{l}\text { Based on MOU } \\
\text { between } \\
\text { school/university, and } \\
\text { the training station is } \\
\text { selected by the } \\
\text { institution. }\end{array}$ & $\begin{array}{l}\text { No MOU between } \\
\text { school/university } \\
\text { and industry, and } \\
\text { the training station } \\
\text { is selected by the } \\
\text { student. }\end{array}$ \\
\hline
\end{tabular}

Table 3 has shown that there is training agreement that signed by student, academic advisor, department chair, coordinator, and supervisor; while on prakerin there is no agreement. In cooperative education, training plan consists of career goal, learning experiences, students tasks, nature and scope of the program, work location, and time frame; on Prakerin, training plan is too general written on "Guidance of Work Practice" published by the Department Chair. The determine of training station of cooperative education is based on Memorandum of Understanding (MOU) between school/university, and the training station is selected by the institution. However, there is no MOU between university and industry, and students themselves select their places of work practice.

Policies needed to implement cooperative education are: (1) for the time being not necessarily to develop acts of cooperative education, but government regulation, minister regulations, inter-ministerial joint decrees, directorate general regulation, and rector regulation, (2) the cooperation can be bilateral between a university and each of associated industries, and can also be more macro level, such as between a university and chamber of commerce or office of industrial affairs at the local government, (3) the schedule of industrial work practice can be flexibly arranged, and (4) temporally, it is not mandatory to industries to provide wages to student.

The industrial work practice for vocational teacher education is very important related to the nature of vocational education itself. Actually, vocational education has to be experience-related; dialogic, sensible, and holistic [6]. Billett [7] has stated that the purposes of vocational education are: preparing for working life, initial preparing of individuals for working life, ongoing development of individuals throughout their working life, and provision of educational experiences facing occupational changes in the future. Therefore, vocational education is basically "education for work".

The activities of industrial work practice for vocational teacher education students also have impact of building their leadership. A vocational teacher is necessary to have effective leadership. Bush [8] has called it as "instructional leadership". According to Bush, the increasing emphasis on managing teaching and learning is the core of "instructional leadership". The instructional leadership of a teacher is very important since the teacher should manage three key activities; teaching, training, and providing resources [9] [10]. In addition, teachers in vocational schools should have values of "entrepreneurial leadership" such as visionary, creative, innovative, independent, hardworking, risk-taking, and entrepreneurial spirit [11] [12]. By the cooperative program for vocational teacher education, the values are expected to be developed.

Most of issues in cooperative education take place at vocational schools. Therefore, some adjustments or modifications have to be done for vocational teacher education programs. The important adjustments are in: program, administrator, advisory committee, coordinator, supervisor, training agreement, and training plan. The program is oriented to build knowledge, skills, and attitudes of students as vocational teacher candidates. In this context, the appropriate administrator is the department chair since he or she can control all cooperative programs. Next, the coordinator is a senior faculty member who has many experiences working at industries. While the advisory committee consists of vice dean academic affairs, department chair, laboratory chairs, representative of students, and representative of related industries. The requirement of supervisor is that he or she not just has leadership in the workplace, but he or she also has to be knowledgeable of teacher education.

\section{Conclusion}

The conclusion of the study are: (1) the cooperative education has some advantages to students, school/university, and industry; (2) the cooperative education is more complex than "prakerin", but more simple than dual system, in terms of the principle, the management system, and the elements of organizational structure; (3) the cooperative education for vocational teacher education has better training program than that of prakerin, especially on the components of training agreement, training plan, and training station; and (4) some policies should be made for applying cooperative education for vocational teacher education related to acts, regulations, forms of collaboration, work schedules, and the status of providing wages for students.

\section{References}

[1] Hill-Jackson, V., \& Lewis, C.W. (2010): Transforming Teacher Education. Stylus Publishing, LLC, Sterling, VA

[2] Danelson, C. (2007): Enhancing Professional Practice: A Framework of Teaching. ASCD, Alexandria, VA.

[3] Vocational Education Act (Amendment) of 2001. United States Congress, Washington, D.C.

[4] Canadian Association for Cooperative Education. Putting Education to Work. CAFCE, Toronto. (Internet: www.cafce.ca/coopdefined.html, accessed "Augus 15, 2014") 
[5] Humbert, J.T. \& Woloszyk, C.A. (1983): Cooperative Education. The National Center for Research in Vocational Education, Columbus, Ohio.

[6] Catts, R., Falk, I., \& Wallace, R. (2011): Vocational Learning: Innovative Theory and Practice. Springer Dordrecht Heidelberg, New York.

[7] Billett, S. (2011): Vocational Education: Purposes, Traditions, and Prospects. Springer, New York.

[8] Bush, T. (2003): Educational Leadership and Management (3rd ed.). SAGE Publishers, Ltd., Thousand Oaks, CA.

[9] Sherlock, D., \& Perry, N. (2008): Quality Improvement in Vocational Education. Kogan Page Limited, Philadelphia, PA.

[10] Sonhadji, A. (2012): Human, Technology, and Education: Toward New Civilization. UM Press, Malang, Indonesia.

[11] Sonhadji, A. (2012): ICT-based Classroom Management for Teacher Training in Vocational Education. SEAMEO VOCTEC Journal, 11 (1): 86-99.

[12] Suyitno, Sonhadji, A., Arifin, I., \& Ulfatin, N. (2014): Entrepreneurial Leadership of Vocational Schools Principals in Indonesia. International Journal of Learning \& Development, 4 (1): 45-64. 